\title{
SPATIO-TEMPORAL EVALUATION OF LONG-TERM EARTHQUAKE EVENTS AND ITS CONTRIBUTION IN GENESIS OF TSUNAMI IN THE INDIAN OCEAN
}

\author{
A. A. $\mathrm{Khan}^{1}$, A. Kumar ${ }^{1,2 *}, \mathrm{P}^{\mathrm{Lal}}{ }^{1}$ \\ ${ }^{1}$ Department of Geoinformatics, Central University of Jharkhand, Ranchi, India - imashif17@gmail.com, preet.lal@cuj.ac.in \\ 2IUCN Commission of Ecosystem Management - amit.kumar@cuj.ac.in amit.iirs@gmail.com
}

\section{Commission V, WG V/7 \& Commission IV, WG IV/6}

\begin{abstract}
KEY WORDS: Earthquake, Tsunami, GIS, Remote Sensing, Hypocentre, Disaster Management
\end{abstract}
\begin{abstract}
:
A very high magnitude earthquake (9.1 MW) triggered a devastating Tsunami in the Indian Ocean on $26^{\text {th }}$ December 2004. The epicentre was located at $3.3^{\circ} \mathrm{N}, 95.8^{\circ} \mathrm{E}$ with a focal depth of $\sim 30 \mathrm{~km}$. The impacts of Tsunami were felt as far away in Somalia, Tanzania and Kenya along the east coast of Africa. Considering the role of earthquake, in the present study the spatio-temporal analysis of long term (1901 to 2019) earthquake events was performed, which recorded by USGS to understand the genesis of Tsunami (2004) in the Indian Ocean. The study exhibited that the maximum frequency of earthquake was observed between the ranges of $4 M W$ to $6 M W$ on the Richter scale during $2001-2010$. There was only one earthquake event $>8 M W$ on the Richter scale $\left(26^{\text {th }}\right.$ December 2004 having depth $30 \mathrm{Km}$ ) in the Indian Ocean recorded during 1901 - 2019. The study exhibited that the maximum earthquake was observed between $30-$ $40 \mathrm{~km}$ below the surface, and primarily of moderate to low magnitudes. The proximity analysis along the major fault line indicates that the maximum earthquakes were in the buffer of $200 \mathrm{~km}$ from fault line in Bay of Bengal. The decadal variation of earthquake exhibits that the maximum number of earthquake events (8427 events) were triggered during the year 2001-2010, whereas during the year 2004, the total 902 earthquake events $>4 M W$ was recorded. The study indicates that the earthquakes $>7 M W$ (on Richter scale) and depth below $30 \mathrm{~km}$ (shallow earthquake) are primarily responsible to major Tsunami events in the Indian Ocean. The very high magnitude ( $>9$ $M W$ on the Richter scale) and shallow depth $(\sim 30 \mathrm{~km})$ are the major cause of 2004 Tsunami and its high level of damage. There were very low frequency $(10-15$ events) of earthquake occurred having magnitude $>7$ and depth $<30 \mathrm{~km}$.
\end{abstract}

\section{INTRODUCTION}

Tsunami, often incorrectly called tidal waves, is a series of waves with a long wavelength and period (time between crests) (Mathur and Udani, 2015). Since 1750, the Indian Ocean has not experienced a natural disaster of such magnitude, with enormous consequences for the region's environment (Sirikulchayanon et al., 2008). On $26^{\text {th }}$ December 2004, an earthquake of $9.1 \mathrm{MW}$ occurred at 0:58:53 GMT in Indian Ocean. The epicentre of earthquake was located at $3.3 \mathrm{~N}, 95.8 \mathrm{E}$ with a focal depth of approximately $30 \mathrm{~km}$ (Lavigne et al., 2013), which triggered a massive Tsunami in the coastal areas of Indian Ocean. Around 280,000 people were killed in South Asia, Southeast Asia, and East Africa (Lavigne et al., 2013). The vertical offset of the ocean floor by 7 to 10 meters on $26^{\text {th }}$ December 2004, Sumatra earthquake displaced massive volumes of water, resulting in a destructive Tsunami. Because of the north-south direction of the fault line, the Tsunami was the strongest in the east-west direction. The wave height in deep water (open ocean) was measured through satellites to be approximately $60 \mathrm{~cm}$, while traveling at a speed of 500 to $800 \mathrm{~km} / \mathrm{hr}$. The velocity decreased to only tens of kilometres per hour in shallow water near the shoreline, depending on the local bathymetry. This, however, resulted in large and destructive waves that reached run-up heights of 20 to 30 meters in Banda Aceh (Saatcioglu et al., 2005). The distribution of aftershocks (U.S. Geological Survey ${ }^{1}$ ) suggests that the rupture extended over a distance of $1500 \mathrm{~km}$ (measured parallel to the arc), but seismic inversions for this event are nonunique and cannot resolve many details of slip, especially along the northern portion of the rupture (Ammon et al. 2005). Furthermore, considering that slip north of $\sim 9^{\circ} \mathrm{N}$ appears to have generated little or no seismic radiation (Lay et al. 2005; Ammon et al. 2005), seismic inversions will only provide a minimum constraint on the extent and amount of slip, and geodetic inversions will be required to provide a maximum (and perhaps more accurate) constraint. However, inversions of the sparse geodetic data that were available prior to this study provided only limited constraints on the amount and distribution of slip (Subarya et al. 2006). Since as per current research knowledge there is no established methods to detect the tsunami being generated due to earthquake or landslide. The phenomenon of tsunami is mainly generated undersea disturbance due to earthquake or landslide or activity near the coast or in the ocean and displace few kilometres to $>1000 \mathrm{~km}$ apart from epicentre. The earthquakes mainly occurs in the region having a high tectonic subduction zones along with tectonic plate boundaries and high seismicity in a regions, caused due to collision of tectonic plates. When a disturbance happens the ocean, the ocean floor rise or falls and effects on water above it and as the water moves up and down, seeking to regain its balance, a tsunami is born. (Borrero, 2005; Kanamori and Kikuchi, 1993; Pelayo and Wiens, 1990; Tsuboi, 2000).

The earthquake of $26^{\text {th }}$ December 2004 occurred due to slip on the subduction interface between the Indo- Australian plate and the Burma microplate below Andaman and Nicobar Islands and Aceh province, Sumatra. The Indian plate has been moving north-east at a rate of approximately $60 \mathrm{~mm} /$ year, subduction under the overriding Burma microplate. The epicentre of the quake was about $155 \mathrm{~km}$ west of Sumatra and about $255 \mathrm{~km}$ south-east of Banda Aceh, Indonesia (Saatcioglu et al., 2005). Along the Java Trench to the southeast of Sumatra, the Australian plate sub ducts beneath the Sunda Shelf in a direction nearly orthogonal to the trench and at a rate of about $63 \mathrm{~mm} /$ year. (Bock, 2003; Michel et al., 2001). Along Sumatra the direction of convergence becomes increasingly oblique towards the north-west and the relative plate slip is partitioned into nearly perpendicular thrusting at the trench and trench-parallel, right-lateral slip at the Sumatran fault (SF) (Fitch, 1972). The strength of a Tsunami depends upon the magnitude of earthquakes occur in the Ocean. There are a number

\footnotetext{
${ }^{1}$ http://neic.usgs.gov/neis/poster/2004/20041226.html

* Corresponding author
} 
of earthquakes occurring in the earth's crust but their magnitude is very low to trigger a Tsunami.

\section{STUDY AREA}

In the present study, the North Indian Ocean comprising the parts of Bay of Bengal was considered as study area. The territory is about $150 \mathrm{~km}$ north of Aceh in Indonesia and separated from Thailand and Myanmar by the Andaman Sea. In this region, the group of Andaman and Nicobar Islands was located, which is a Union territory of India comprising 572 islands of which 37 are inhabited, are a group of islands at the juncture of the Bay of Bengal and Andaman Sea. There are 572 islands in the territory having an area of $8,249 \mathrm{~km}^{2}$. Of these, about 38 are permanently inhabited. The islands extend from $6^{\circ}$ to $14^{\circ}$ North latitudes and from $92^{\circ}$ to $94^{\circ}$ East longitude. The Andaman and Nicobar Islands have a tropical rainforest canopy, made of a mixed flora with elements from Indian, Myanmar, Malaysian and endemic floral strains. So far, about 2,200 varieties of plants have been recorded, out of which 200 are endemic and 1,300 do not occur in mainland India. As of 2011 Census of India, the population of the Union Territory of Andaman and Nicobar Islands was 379,944, of which $202,330(53.25 \%)$ were male and $177,614(46.75 \%)$ were female.

\section{METHODOLOGY}

This study aims to analyse the earthquakes events, which is obtained from USGS earthquake portal ${ }^{2}$. Earthquakes of different intensities were plotted in the GIS environment where the events were analysed with reference to its spatio-temporal occurrences, decadal occurrences, magnitude, depth of occurrences, proximity to major fault line near the Andaman and Nicobar Islands. Fault line has been taken from and proximity analysis at various proximity viz., $>5 \mathrm{~km}, 5-10 \mathrm{~km}, 10-50 \mathrm{~km}, 50-100 \mathrm{~km}$, and $>100$ $\mathrm{km}$ from major fault line. The earthquake events of occurred during 2004 was analysed with reference to the earthquake events of a century (1901 to 2019).

\section{RESULTS AND DISCUSSION}

The earthquakes occurred during 1901 to 2019 was analysed in GIS environment showing its magnitude and its depth. The maximum number of earthquakes was observed in the range of 4$5 \mathrm{MW}$ on Richter scale (figure 1). Usually, it takes an earthquake with a Richter magnitude exceeding 7.5 $M W$ to produce a destructive tsunami at specific depth. The earthquakes in this range is of very low intensity. Maximum frequency of earthquake magnitude occurs in the range of 5-6 $M W$ in 2004, which releases low amounts of energy to trigger Tsunami (figure 2). Earthquake magnitude more than 8 is observed in 2004, which triggered a massive Tsunami near Sumatra Island (figure 2). The energy released during this earthquake is sufficient to trigger a devastating tsunami. Scatterplots provides better understanding of the frequency of earthquakes occurred from 1901 to 2019. The maximum earthquake belongs to less than 6 magnitudes on the Richter scale. A very few Earthquakes belong to above 8 magnitudes on the Richter scale. An increase in the trend of earthquake event was witnessed from the scatterplot (Figure 4). Since the number of events of earthquakes was increased during the post 1960s, but the magnitude trend was observed decreasing, means earthquake event occurring with less magnitude. This may be attributed to the movement of oceanic plate at various intensity leading to earthquake of varied intensity/ magnitude. From 19012010 , the depth of the maximum earthquake located between 10-

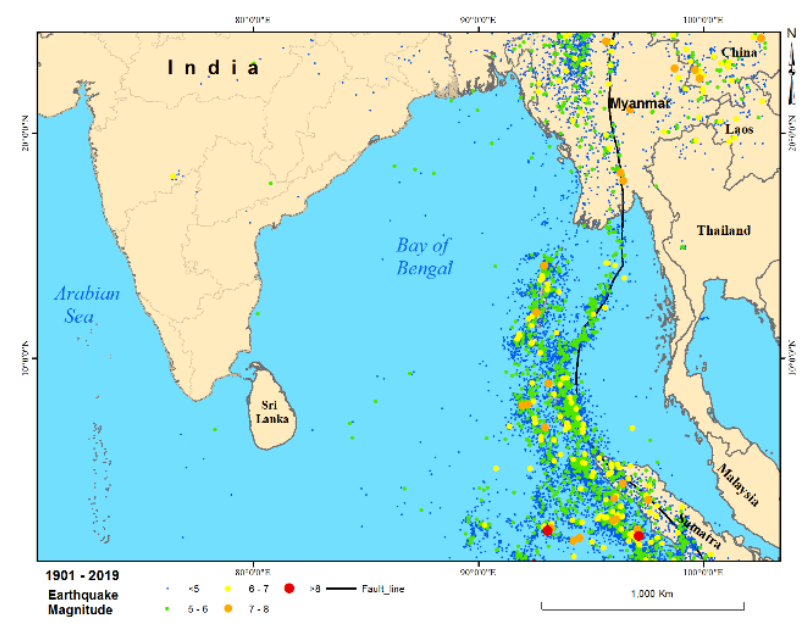

Figure 1. Spatio-temporal distribution of earthquake based on its magnitude during 1901 to 2019

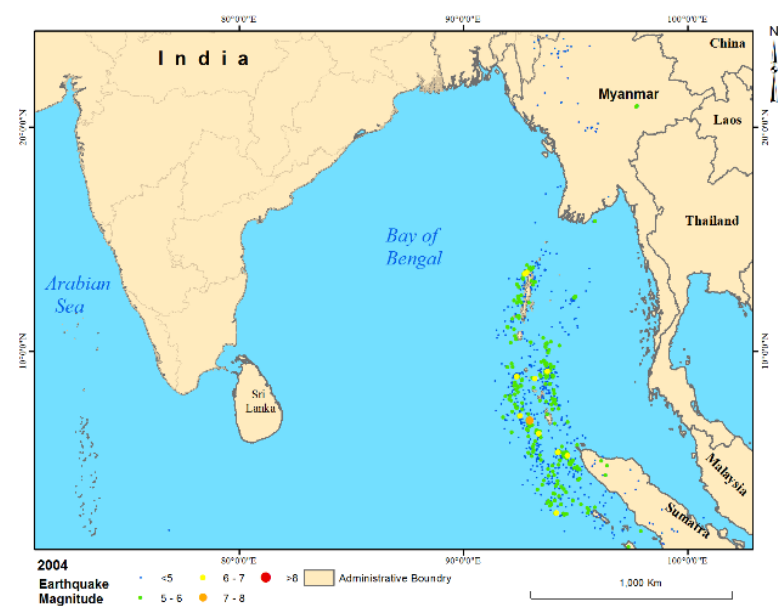

Figure 2. Spatio-temporal distribution of earthquake based on its magnitude during 2004 in Indian Ocean

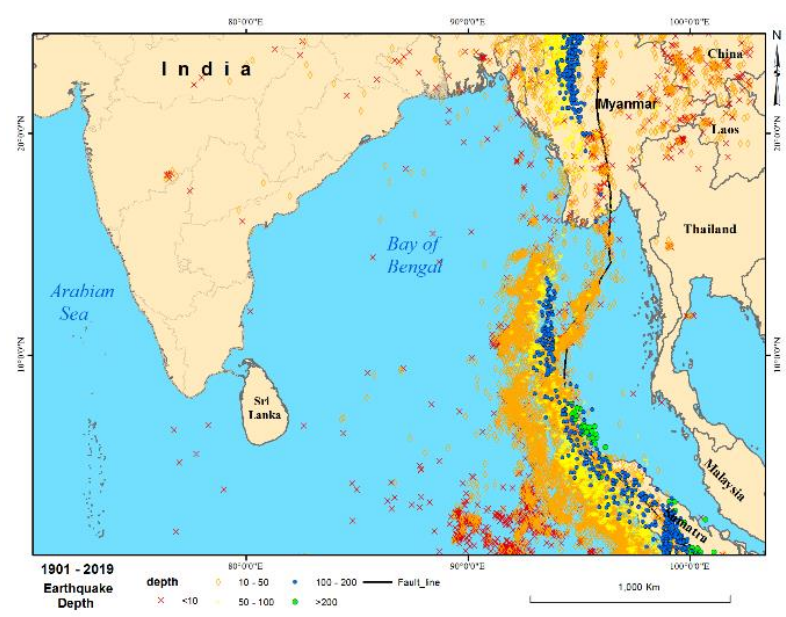

Figure 2. Spatio-temporal distribution of earthquake based on depth to hypocentre during $1901-2019$

\footnotetext{
2 http://earthquake.usgs.gov/
} 
$50 \mathrm{~km}$ range (figure 3) and having magnitude between 4.0 and 6.0. The study exhibited that the nearer the depth of earthquake, the higher the devastation. Increase in distance of surface from the focus, decrease in the impacts of the earthquake on the surface. Earthquake magnitude $>4$ was analysed from 1901 to 2019 with a sum of occurrence of earthquake in decadal time scale. As per USGS, very less number of earthquakes was recorded till 1970s. The least event of earthquakes captured was one in $1901-1910$ followed by 4 events in 1911-20, 12 events in 1921-30, 15 events between 1931-40 as well as in 1941-50 and 50 events in 1961-70.

The highest number (8427 events) of earthquake events occurred was during 2001-10 followed by 3581 events during 2011-18
(March), 1232 events in 1991-2000, 1164 events in 1981-90 and 509 events in 1971-80 in Indian ocean. In year 2004, 902 events of earthquake triggered, which shows a huge number of earthquakes. The less number of events captured till 1970s may be attributed to limitation of observation, recording station, methods etc. The maximum frequency of earthquake events was recorded at the depth between 10 to $50 \mathrm{~km}$ in the year 2004. It is difficult to conclude the magnitude of an earthquake on the basis of its depth (figure 5). The correlation analysis of magnitude and depth of the earthquake events (1901-2019) exhibits that the more occurrence of earthquake with higher magnitude $(>7 \mathrm{MW})$ at the shallow depth $(<50 \mathrm{~km})$.

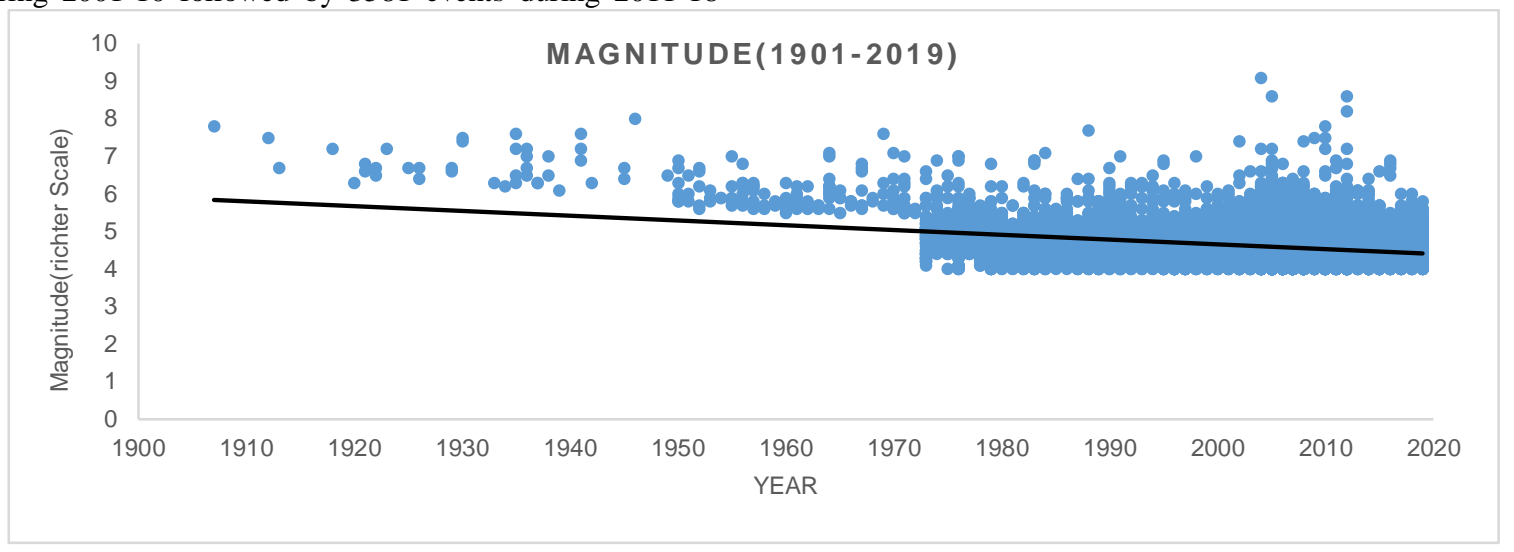

Figure 3. Trend of number of Earthquake from year 1901 - 2019

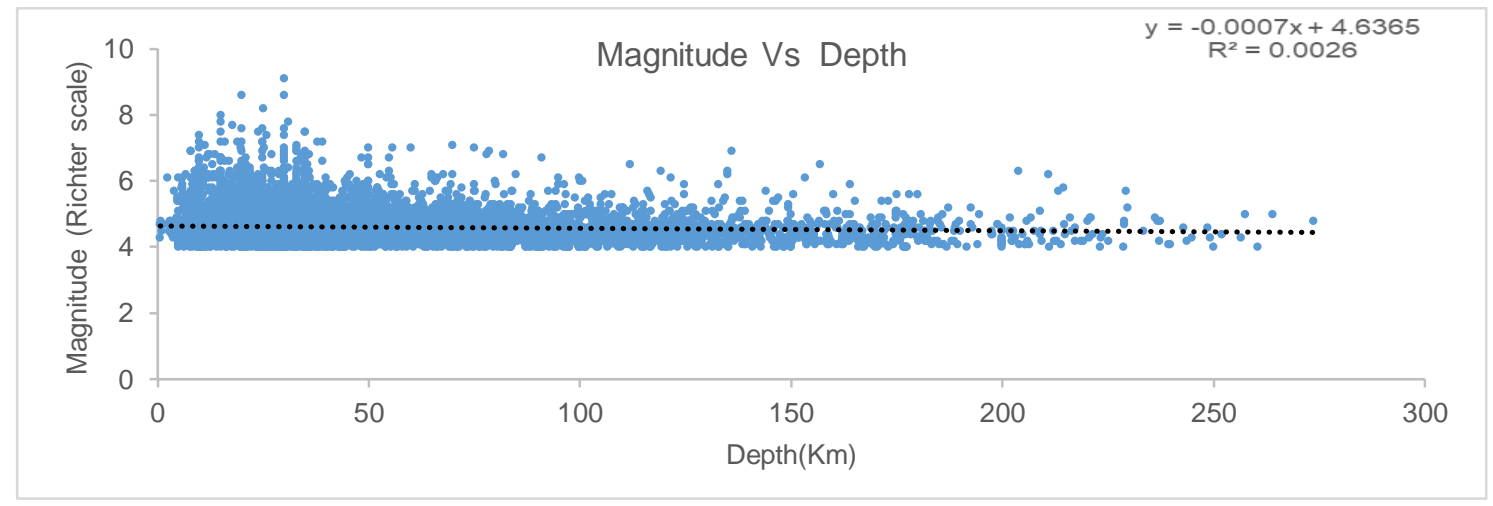

Figure 4. Correlation Map of Magnitude v/s Depth

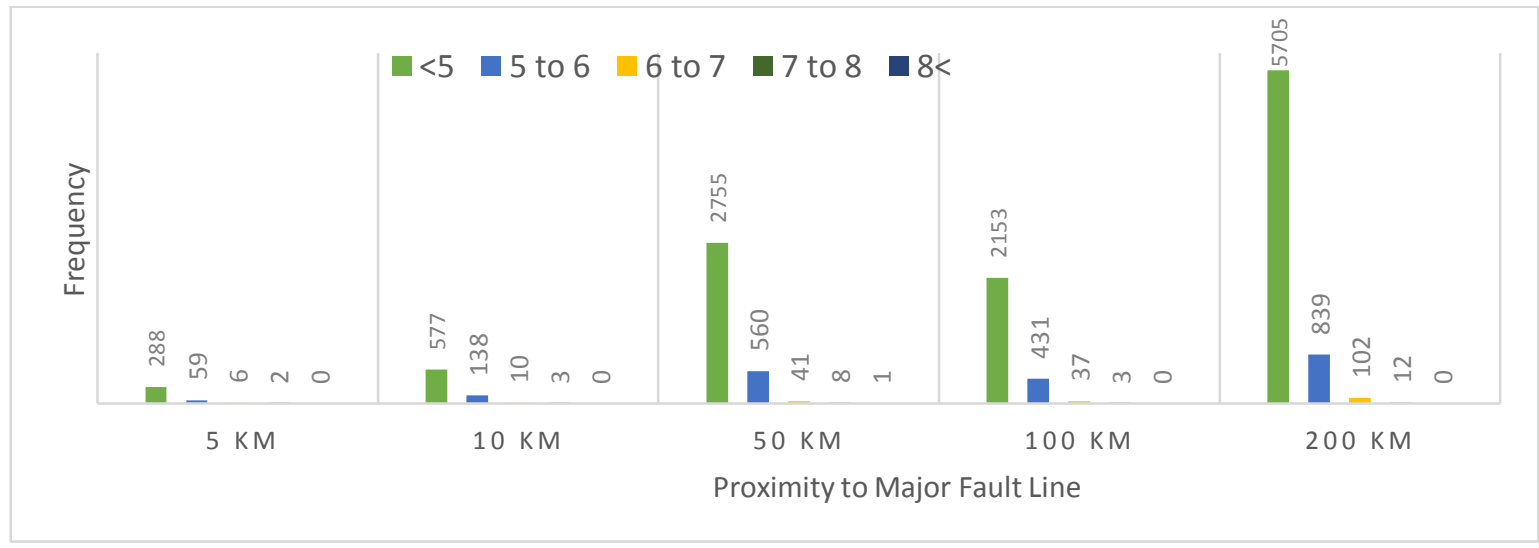

Figure 5. Number of earthquake events in the proximity of major fault line 


\begin{tabular}{|c|c|}
\hline Year & $\begin{array}{c}\text { Events of Earthquake with } \\
\text { Frequency }(\boldsymbol{M W} \mathbf{4})\end{array}$ \\
\hline $1901-1910$ & 1 \\
\hline $1911-1920$ & 4 \\
\hline $1921-1930$ & 12 \\
\hline $1931-1940$ & 15 \\
\hline $1941-1950$ & 45 \\
\hline $1951-1960$ & 50 \\
\hline $1961-1970$ & 509 \\
\hline $1971-1980$ & 1164 \\
\hline $1981-1990$ & 1232 \\
\hline $1991-2000$ & 8427 \\
\hline $2001-2010$ & 3581 \\
\hline $2011-2019$ & Frequency $(\boldsymbol{M W}>\mathbf{4})$ \\
\hline Year & 902 \\
\hline 2004 & \\
\hline
\end{tabular}

Table 1. Number of Earthquake Events in different decade between 1901 - 2019 and year 2004

The depth of the earthquake events were analysed with reference to its depth. The study exhibits that the most events of earthquake occurred between $30-40 \mathrm{~km}$ vertical depth i.e., 7126 events, followed by 2379 events in $10-20 \mathrm{~km}$ vertical depth, 1958 events at $20-30 \mathrm{~km}$ depth and 1278 events $>100 \mathrm{~km}$ depth. Least events of earthquake $(163$ events) was occurred at $<10 \mathrm{Km}$ vertical depth followed by 464 events at $80-100 \mathrm{~km}$ vertical depth and 659 events at $60-80 \mathrm{~km}$ vertical depth. It is to note that in 2004 , the most number of events i.e., 455 events occurred at $30-40 \mathrm{~km}$ depth followed by 192 events at $20-30 \mathrm{~km}$ vertical depth and 94 events at $10-20 \mathrm{~km}$ vertical depth. Least event was recorded (10 events) at $<10 \mathrm{~km}$ vertical depth followed by 21 events at $80-100 \mathrm{~km}$ vertical depth, 27 events at $60-80$ $\mathrm{km}$ depth, and 30 events at more than $100 \mathrm{~km}$ depth and 73 events at $40-60 \mathrm{~km}$ vertical depth. Here all events are the recorded occurrence events of earthquakes events.

The proximity analysis $(<5 \mathrm{~km}, 5-10 \mathrm{~km}, 10-50 \mathrm{~km}, 50-100$ $\mathrm{km}$ and 100-200 km) of earthquakes events along the major fault line was performed during the period 1901-2019 to deduce the geography of earthquake events in the Indian Ocean (Figure 5, Figure 6). The study exhibited that the maximum number of earthquakes events of $<4 M W$ was observed within the proximity of 100-200 km from the major fault line. Further, a decreasing trend in the frequency of earthquakes of 5 to 8 magnitude was observed (Figure 6). The maximum number of earthquakes were observed in the proximity of 100-200 km zone from the fault line. Only one earthquake event was observed having magnitude $>8$ in the proximity of 50-100 $\mathrm{km}$ from the major fault line.

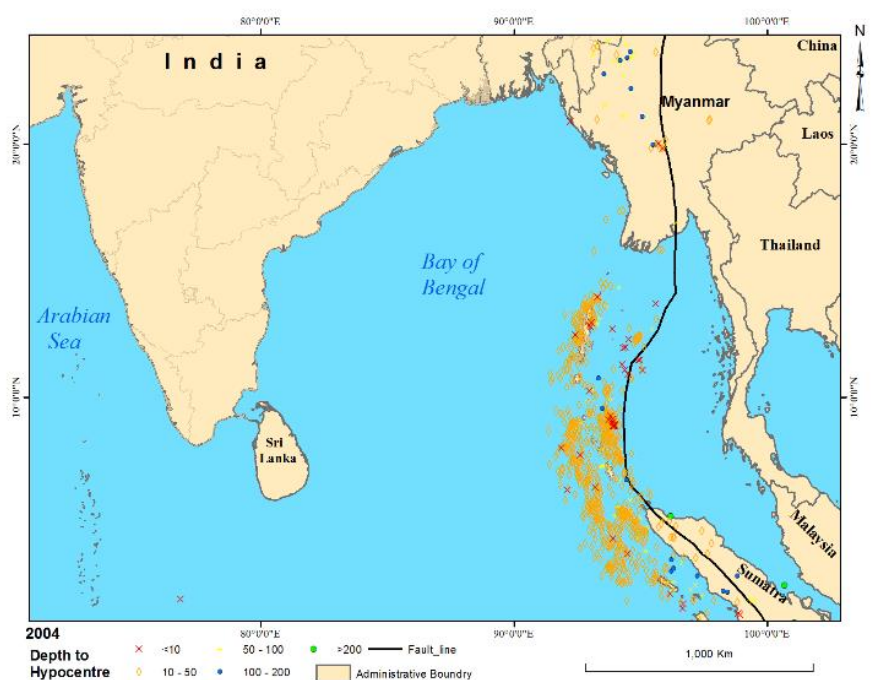

Figure 6. Depth to Hypocentre

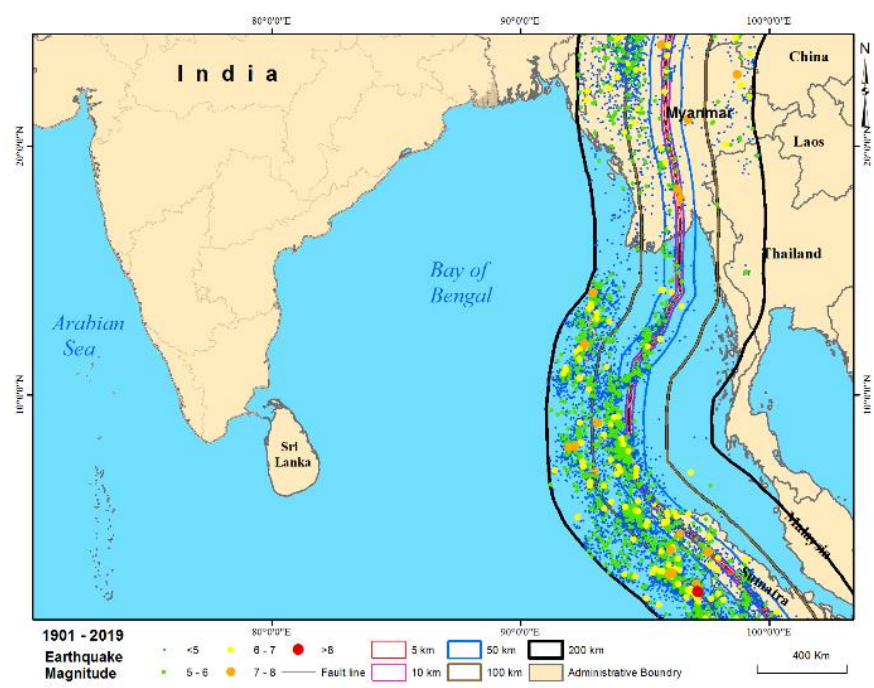

Figure 7. Earthquake events based on magnitude with in the proximity of major fault line in Indian Ocean

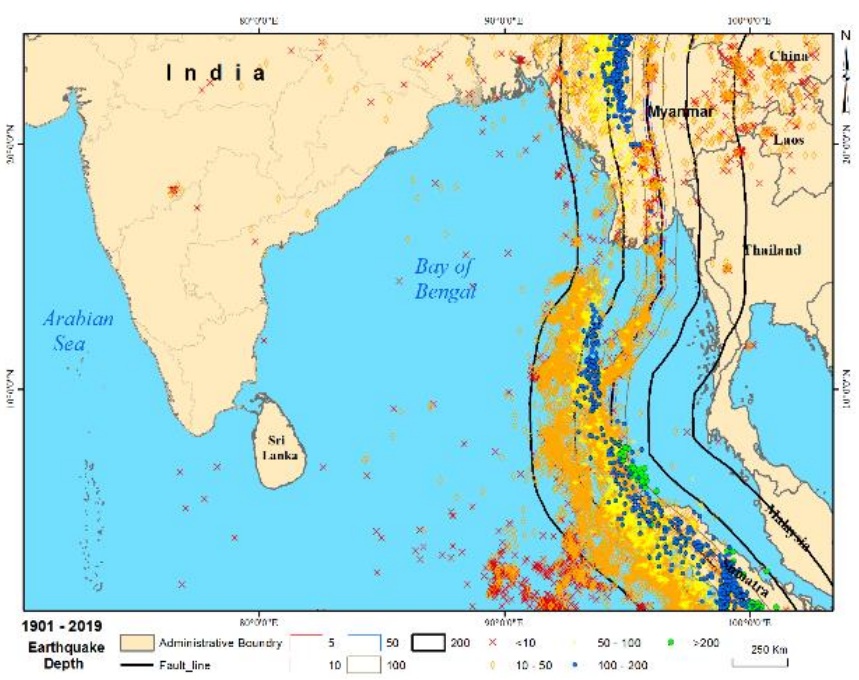

Figure 8 . Proximity analysis based on depth to hypocentre along the major fault line 
Analysing the USGS based earthquake events occurred in Indian ocean based on its various characteristics, it is concluded that earthquake exceeding with magnitude 7.5 occurring near the ocean surface or $<50 \mathrm{~km}$ depth triggers the devastating tsunami. The same result has been reported by various studies done on various regions around the globe (Annaka et al., 2007; Fujii et al., 2011; Satake, 1994; Satake et al., 1996; Tanioka and Sataka, 1996; Tomazevic, 1999). As per Global Historical Tsunami Database (GHTD) about $85 \%$ - $89 \%$ of tsunami are generated by large earthquakes or landslide.

\section{CONCLUSION}

The study concludes that the maximum number of earthquake events having 4 to $6 \mathrm{MW}$ on the Richter scale has been occurring along the fault line does not contribute in the genesis of Tsunami. The earthquakes (>7.5 MW) observed are mainly responsible for the formation of destructive Tsunami in the Indian Ocean. It is to note that there are very less frequency of earthquake events, which had magnitude $>7.5$ on the Richter scale. Generally, earthquake of higher magnitude (>7.5) primarily at shallow depth $(<50 \mathrm{~km})$ trigger the devastating Tsunami. The proximity analysis along the major fault line concludes that the maximum earthquakes occur in the proximity of $200 \mathrm{~km}$ along the fault line. It is to mark that since 2004 (>9.1 MW), no significant earthquake event was recorded of such high magnitude. The region is tectonically activated and frequency of high magnitude earthquake events was observed post 1960 periods, primarily during 2001-10. Although, earthquake of $M W>8$ occurred at the depth below $200 \mathrm{~km}$ which does not conclude Tsunami eventually. In future work, subsidence and upliftment of earth's surface due to earthquake generated Tsunami using SAR offset tracking (Lal et al., 2018; Sun et al., 2017) or interferometry approach (Fornaro and Pascazio, 2014; Massonnet et al., 1993) may be considered for better understanding of deformation occurred during 2004 earthquake and Tsunami.

\section{ACKNOWLEDGEMENT}

We thank the anonymous reviewers for their careful reading of our manuscript and their insightful comments and suggestions. The authors would like to express their gratitude to USGS (http://earthquake.usgs.gov/), from where the earthquake data were downloaded and used in the present study.

\section{REFERENCES}

Ammon, C.J., Ji, C., Thio, H.-K., Robinson, D., Ni, S., Hjorleifsdottir, V., Kanamori, H., Lay, T., Das, S., Helmberger, D., Ichinose, G., Polet, J., Wald, D., 2005. Rupture process of the 2004 Sumatra-Andaman earthquake. Science 308, 1133-1139. doi:10.1126/science. 1112260

Annaka, T., Satake, K., Sakakiyama, T., Yanagisawa, K., Shuto, N., 2007. Logic-tree Approach for Probabilistic Tsunami Hazard Analysis and its Applications to the Japanese Coasts, in: Satake, K., Okal, E.A., Borrero, J.C. (Eds.), Tsunami and Its
Hazards in the Indian and Pacific Oceans, Pageoph Topical Volumes. Birkhäuser, Basel, pp. 577-592. https://doi.org/10.1007/978-3-7643-8364-0_17

Bock, Y., 2003. Crustal motion in Indonesia from Global Positioning System measurements. J. Geophys. Res. 108, 2367. doi:10.1029/2001JB000324

Borrero, J.C., 2005. Field Survey of Northern Sumatra and Banda Aceh, Indonesia after the Tsunami and Earthquake of 26 December 2004. Seismological Research Letters 76, 312-320. https://doi.org/10.1785/gssrl.76.3.312

Fitch, T.J., 1972. Plate convergence, Transcurrent faults, and internal deformation adjacent to Southeast Asia and the western Pacific. J. Geophys. Res. 77, 4432-4460. doi:10.1029/JB077i023p04432

Fornaro, G., Pascazio, V., 2014. SAR interferometry and tomography: theory and applications. In: Communications and Radar Signal Processing, Academic Press Library, Elsevier, 2, 1043-1117. doi:10.1016/B978-0-12-396500-4.00020-X

Fujii, Y., Satake, K., Sakai, S., Shinohara, M., Kanazawa, T., 2011. Tsunami source of the 2011 off the Pacific coast of Tohoku Earthquake. Earth Planet Sp 63, 815-820. https://doi.org/10.5047/eps.2011.06.010

Kanamori, H., Kikuchi, M., 1993. The 1992 Nicaragua earthquake: a slow tsunami earthquake associated with subducted sediments. Nature 361, 714-716. https://doi.org/10.1038/361714a0

Lal, P., Vaka, D.S., Rao, Y.S., 2018. Mapping Surface flow velocities of Siachen and Gangotri glaciers using TERRASAR-X and SENTINEL-1A data by intensity tracking. ISPRS Annals of Photogrammetry, Remote Sensing and Spatial Information Sciences, IV-5, 325329.https://doi.org/10.5194/isprs-annals-IV-5-325-2018

Lay, T., Kanamori, H., Ammon, C.J., Nettles, M., Ward, S.N., Aster, R.C., Beck, S.L., Bilek, S.L., Brudzinski, M.R., Butler, R., DeShon, H.R., Ekström, G., Satake, K., Sipkin, S., 2005. The great Sumatra-Andaman earthquake of 26 December 2004. Science 308, $1127-$ 1133. doi:10.1126/science. 1112250

Liew, S. C. and He, J. (2008) Uplift of a Coral Island in the Andaman Sea Due to the 2004 Sumatra Earthquake Measured Using Remote Sensing Reflectance of Water, IEEE Geoscience and Remote Sensing Letters, 5(4), pp. 701-704.

Massonnet, D., Rossi, M., Carmona, C., Adragna, F., Peltzer, G., Feigl, K., Rabaute, T., 1993. The displacement field of the Landers earthquake mapped by radar interferometry. Nature 364, 138-142. doi:10.1038/364138a0

Mathur, D.K., Udani, P.M., 2015. Tsunami Detection \& Assessment Using Remote Sensing and GIS. International Journal of Engineering Research and General Science 3. 
Michel, G.W., Yu, Y.Q., Zhu, S.Y., Reigber, C., Becker, M., Reinhart, E., Simons, W., Ambrosius, B., Vigny, C., Chamot-Rooke, N., Le Pichon, X., Morgan, P., Matheussen, S., 2001. Crustal motion and block behaviour in SE-Asia from GPS measurements. Earth and Planetary Science Letters, 187, 239-244. doi:10.1016/S0012-821X(01)00298-9

Morse, J. L. (2012) A multitemporal analysis of tsunami impact on coastal vegetation using remote sensing: A case study on Koh Phra Thong Island, Thailand. Natural Hazards, 64. 667:689. doi: 10.1007/s11069-012-0261-y.

Pelayo, A.M., Wiens, D.A., 1990. The November 20,1960 Peru Tsunami Earthquake: Source mechanism of a slow event. Geophysical Research Letters 17, 661664. https://doi.org/10.1029/GL017i006p00661

Römer, H., Willroth, P., Kaiser, G., Vafeidis, A.T., Ludwig, R., Sterr, H., Revilla Diez, J., 2012. Potential of remote sensing techniques for tsunami hazard and vulnerability analysis - a case study from Phang-Nga province, Thailand. Natural Hazards and Earth System Science, 12, 2103-2126. https://doi.org/10.5194/nhess12-2103-201

Saatcioglu, M., Ghobarah, A. and Nistor, I. (2005) Effects of the December 26, 2004 Sumatra Earthquake, ISET Journal of Earthquake Technology, 42(457), 7994.

Satake, K., 1994. Mechanism of the 1992 Nicaragua Tsunami Earthquake. Geophysical Research Letters 21, 2519-2522. https://doi.org/10.1029/94GL02338

Satake, K., Shimazaki, K., Tsuji, Y., Ueda, K., 1996. Time and size of a giant earthquake in Cascadia inferred from Japanese tsunami records of January 1700. Nature 379, 246-249. https://doi.org/10.1038/379246a0

Sirikulchayanon, P., Sun, W. and Oyana, T. J. (2008) Assessing the impact of the 2004 tsunami on mangroves using remote sensing and GIS techniques, International Journal of Remote Sensing. 3553-3576 doi:
10.1080/01431160701646332.

Subarya, C., Chlieh, M., Prawirodirdjo, L., Avouac, J.P., Bock, Y., Sieh, K., Meltzner, A.J., Natawidjaja, D.H., McCaffrey, R., 2006. Plate-boundary deformation associated with the great Sumatra-Andaman earthquake. Nature, 440, 46-51. doi:10.1038/nature04522

Sun, L., Muller, J.-P., Chen, J., 2017. Time Series Analysis of Very Slow Landslides in the Three Gorges Region through Small Baseline SAR Offset Tracking. Remote Sens (Basel) 9, 1314. doi:10.3390/rs9121314

Suppasri, A., Koshimura, S., Matsuoka, M., Gokon, H., Kamthonkiat, D., 2012. Application of remote sensing for tsunami disaster. Remote sensing of planet earth $143-168$.

Tanioka, Y., Sataka, K., 1996. Fault parameters of the 1896 Sanriku Tsunami Earthquake estimated from Tsunami Numerical Modeling. Geophysical Research Letters 23, 1549-1552. https://doi.org/10.1029/96GL01479

Tomazevic, M., 1999. Earthquake-Resistant Design of Masonry Buildings, Series on Innovation in Structures and Construction. Imperial College Press. https://doi.org/10.1142/p055.

Tsuboi, S., 2000. Application of Mwp to tsunami earthquake. Geophysical Research Letters 27, 31053108. https://doi.org/10.1029/2000GL011735

Wang, J.-F., Li, L.-F., 2008. Improving Tsunami Warning Systems with Remote Sensing and Geographical Information System Input. Risk Analysis 28, 1653-1668. https://doi.org/10.1111/j.15396924.2008.01112.x 